\title{
UNIVERSITYOF
}

FORWARD

THINKING

WESTMINSTER用

WestminsterResearch

http://www.westminster.ac.uk/westminsterresearch

Introduction: The Responsibility to Protect after the Arab Spring

Hehir, A. and Pattison, J.

This is a copy of the published version of a paper published in Cooperation and Conflict November 18, 20150010836715612853

https://dx.doi.org/10.1177/0010836715612853

(C) The Author(s) 2015 This article is distributed under the terms of the Creative Commons Attribution 3.0 License (CC-BY 3.0) (http://www.creativecommons.org/licenses/by/3.0/) which permits any use, reproduction and distribution of the work without further permission provided the original work is attributed as specified on the SAGE and Open Access page (http://www.uk.sagepub.com/aboutus/openaccess.htm).

The WestminsterResearch online digital archive at the University of Westminster aims to make the research output of the University available to a wider audience. Copyright and Moral Rights remain with the authors and/or copyright owners.

Whilst further distribution of specific materials from within this archive is forbidden, you may freely distribute the URL of WestminsterResearch: ((http://westminsterresearch.wmin.ac.uk/)).

In case of abuse or copyright appearing without permission e-mail repository@westminster.ac.uk 


\section{Introduction: The Responsibility to Protect after the Arab Spring}

\section{Aidan Hehir and James Pattison}

Cooperation and Conflict

(C) The Author(s) 2015

Reprints and permissions: sagepub.co.uk/journalsPermissions.nav DOI: I0.II77/00I08367|56I2853 cac.sagepub.com

@SAGE

\section{Introduction}

The Responsibility to Protect (R2P) has become the pre-eminent framework for discussing humanitarian intervention and issues related to human rights protection generally. Its origins lie in the 2001 report of the International Commission on Intervention and State Sovereignty (ICISS), which first proposed the notion of the 'Responsibility to Protect'. Its adoption at the 2005 United Nations (UN) World Summit, with over 160 heads of state in attendance, has led to numerous inter-disciplinary debates within academia and beyond. The R2P has often been controversial, but the eruption of the 'Arab Spring' in late 2010 has constituted the concept's most exacting test and prompted a further spike in interest in both its efficacy and desirability. The articles in this special issue assess the R2P in light of the events during, and debates surrounding, the Arab Spring. Together, they constitute a uniquely focused assessment of this significant and influential doctrine.

This introduction will first consider in more detail the importance of the R2P for the Arab Spring, before going on to consider, conversely, the importance of the Arab Spring for the R2P. It will then outline the focus of the special issue and the two central questions with which it is concerned. Finally, it will provide an overview of the debate in the articles and how they address the two central questions.

\section{The importance of the Responsibility to Protect for the Arab Spring and vice versa}

The Arab Spring comprised a dramatic series of protests and revolutions against authoritarian and repressive regimes. It is widely viewed as starting in Tunisia in December 2010 when the street vendor, Mohamed Bouazizi, set himself on fire in protest at police harassment. This led to protests and a popular uprising that in turn led to the overthrow of Zine El Abidine Ben Ali's government. The protest movements spread to other states, including Yemen, Bahrain, Algeria, Jordon and, notably, Egypt, where Hosni Mubarak's regime eventually succumbed to weeks of pressure from large-scale protests in Cairo and elsewhere. In Libya, anti-Gaddafi protestors soon controlled Benghazi, the

\footnotetext{
Corresponding author:

James Pattison, University of Manchester, Manchester, MI3 9PL, UK.

Email: james.pattison@manchester.ac.uk
} 
second-largest city in the country, and the government launched a crackdown in response. In Syria, thousands of protesters called for the resignation of President Basher al-Assad in various cities across the country, leading to a violent response by the Assad regime and, later in 2011, the armed uprising of the Free Syrian Army.

The international reaction to the Arab Spring was initially one of significant optimism and some degree of support, albeit nervous. There was a sense that it could lead to longlasting, democratic rule in the Middle East and that this was an important moment for the region. In Libya, the crackdown by the Gaddafi regime on the protesters led to robust action by the international community. Resolution 1970 referred the situation to the International Criminal Court and imposed an arms embargo, as well as a travel ban and asset freeze on many members of the Gaddafi regime. In Resolution 1973, passed in March 2011, the UN Security Council authorised the imposition of a no-fly zone and the use of all necessary means to protect the Libyan population under Chapter VII of the UN Charter. This intervention was widely framed in the academic, public and political debate in the context of the R2P. ${ }^{1}$ That said, it is moot how important the R2P was for motivating the intervention in Libya (see, for instance, the articles by Hehir, Morris and Glanville in this special issue). In Syria, the R2P has similarly informed the debates about how the international community should react to the subsequent civil war between the Assad regime, the Free Syrian Army and, increasingly, Islamic extremists. Yet the USA and other states backed away from undertaking humanitarian intervention in 2013 in response to chemical weapons attacks by the Assad regime and, ultimately, little has been done to stop the bloodshed in Syria. For some, this shows the R2P fails to have any impact, but others (such as Glanville in his contribution) contest this.

Unfortunately, much of the optimism surrounding the Arab Spring has since dissipated, as many of the states where there were revolutions are currently enduring severe instability. Libya is currently experiencing civil war, with fighting between Islamist rebels and government forces, particularly around Benghazi. Egypt is again subject to authoritarian rule, but this time this rule is defended by some of the advocates of the overthrow of Mubarak, fearful that the alternative - such as the Muslim Brotherhood have been or could be even worse. As already noted, Syria has been subject to a bloody civil war, with the death toll estimated at over 220,000 (Jones and Shaheen, 2015).

This so-called subsequent 'Arab Winter' (Kurzman et al., 2013) has meant that the potential for stable democratic rule has given way to a fear of the entrenchment of authoritarian governments states and, potentially worse, bloody civil, intrastate sectarian wars where mass atrocities abound. The Arab Spring has therefore given rise to several R2P cases under 'pillar one' of the doctrine as outlined in the 2009 report by the UN Secretary General (UNSG) - 'the protection responsibilities of states' - where states are required to ensure that their own populations are not subject to war crimes, crimes against humanity, ethnic cleansing, and genocide (Ban, 2009). Many have failed in this responsibility. This has meant that the international community has a remedial, inter-national responsibility to respond, under R2P's 'pillar two' if possible - international assistance and capacity-building - but most clearly under 'pillar three' - 'timely and decisive response' (Ban, 2009). The international community's success in meeting this responsibility has been disputed, but clearly subject to some obvious failures, most notably in Syria. The so-called Arab Winter seems likely to give rise to several future cases where 
the international community will be called on to respond. Given that much of the domestic and international reaction will be likely to be framed by the $\mathrm{R} 2 \mathrm{P}$, the reactions under the R2P umbrella (whether really motivated by the R2P or not) are likely to be important for future events in the Middle East. To that extent, the R2P is of vital importance to the Arab Spring and Winter.

Conversely, the Arab Spring is hugely important for the R2P. The historian Martin Gilbert has referred to the R2P as the 'most significant adjustment to national sovereignty in 360 years' (in Axworthy and Rock, 2009: 69). In a similar vein, Ramesh Thakur and Thomas Weiss (2009) claim that the R2P is the 'most dramatic development of our timecomparable to the Nuremberg trials and the 1948 Convention on Genocide' (p. 23). Both statements were made prior to 2011 and the Arab Spring. If anything, the Arab Spring appears to have made the R2P even more important, if not for practice (the contributors in this special issue disagree about its political import), certainly for its relevance for debates not simply about humanitarian intervention, but also prevention of mass atrocities more generally. As noted above, debates in academia as well as public debates now commonly frame discussions not only about the potential case for military intervention in terms of the R2P, but also for atrocity prevention strategies and the import of states protecting their own populations. The Arab Spring seems to have exacerbated this tendency.

Yet, the R2P is still a fairly young doctrine, having only been accepted by states in 2005 and formulated in the three pillar approach in the report of the UNSG in 2009 (Ban, 2009). As such, it lacks many cases to test its efficacy and desirability. The uprisings in the Arab world since 2011 provide numerous important cases for the R2P doctrine; how the R2P is perceived as reacting to them will be crucial for the future of the doctrine. If it is seen, for instance, as being effective, then it may help to garner political support surrounding the doctrine. Alternatively, if it is seen as ineffective or morally problematic, the R2P may fade, like the related notion of 'human security' arguably has done. The Arab Spring is therefore vital for the R2P.

It is therefore the opportune time to reconsider R2P doctrine in light of the Arab Spring. Accordingly, this special issue is driven by two central, related questions: (i) In light of the Arab Spring, how efficacious is the R2P at addressing mass atrocities? (ii) Is the R2P a desirable way of addressing mass atrocities, given the Arab Spring? The six contributions address these questions. In doing so, their focus is not on the Arab Spring per se, but rather the R2P after this hugely significant event.

\section{The road ahead}

The first two articles consider the UN Security Council resolutions on the Arab Spring. Jess Gifkins focuses, in particular, on the claim that the R2P has been weakened by the international response to the Libyan intervention. It was widely claimed, for instance, that the BRICS (Brazil, Russia, India, China and South Africa) countries - in particular, Russia and China - were frustrated with the North Atlantic Treaty Organization (NATO)-led bombing campaign in Libya and, especially, the alleged misuse of Resolution 1973 to facilitate regime change in Libya. Others (e.g. Bellamy, 2014) have claimed that the R2P has been used many more times since Libya and that the claims of post-Libya 'blowback' on the R2P are overstated. Gifkins takes this argument further, arguing that the R2P was in 
fact much more contentious within the Security Council prior to the Arab Spring. For her, although there remains contention around the international remedial responsibility to protect, the protection responsibilities of states are more frequently highlighted since the Arab Spring. To that extent, despite some contestation, the Security Council is becoming increasingly persuaded of the R2P's merits. This, she argues, was clear during the Arab Spring, during which the Security Council showed an augmented willingness to apply the R2P.

Aidan Hehir takes a more sceptical line (although one that is potentially consistent with Gifkins' analysis). For Hehir, the R2P lacks any influence and this is shown by the Arab Spring, which has demonstrated that the R2P remains, at best, a contested concept with limited impact on the behaviour of states. This is clear, he claims, in the responses to Libya, Bahrain and Syria. Such cases are driven, he argues, by narrowly conceived self-interest of states rather than the R2P norm. Hehir accepts, with others (e.g. Gifkins), that the pillar one protection responsibilities of states are oft cited, but, for him, what is potentially value-added about the $\mathrm{R} 2 \mathrm{P}$ is the international remedial responsibility to protect. It is this aspect, he claims, that is crucially absent from UN Security Council resolutions related to the Arab Spring.

Luke Glanville contests much of what Hehir argues; Glanville states that 'the R2P norm in fact has a very real and readily observable impact on the behaviour of states'. Drawing on recent constructivist scholarship, Glanville helpfully distinguishes between the potential 'regulative' and 'constitutive' effects of norms. The former - regulative effects - constrain or encourage states to behave in certain ways, whereas the latter - the constitutive effects - constitute identities and interests. Glanville, contra Hehir, argues that these effects can be found in regard to the international remedial R2P, and not simply the domestic protection responsibilities of states. Yet, he argues that the R2P norm should not be seen as requiring the responsibility to always engage in direct action to address ongoing mass atrocities (given that there may be no appropriate course of action that will be better than doing nothing), but rather that there is an obligation to 'try'. More positively, for Glanville, the intervention in Libya cannot be explained without reference to the power of the R2P. In his words, 'the impact of R2P and related ideas of human protection in this case is clear'. He accepts that the international community has failed to live up to its R2P in the case of Syria, but argues strongly that this does not mean that the R2P lacks impact since, for instance, states have at least felt the need to justify their inadequate response.

A less optimistic reading is presented by Justin Morris. For him, there is a notable concern about the inclusion of humanitarian intervention within the R2P doctrine. He worries that R2P has become toxic since the Arab Spring due to the intervention in Libya. He argues, contra Gifkins and Glanville, that the lack of action in Syria is due to postLibyan blowback. According to Morris, this has led to resurgent concerns about the R2P and, in particular, the use of force. The solution, he suggests, is clear: 'the excision of its non-consensual, coercive military aspects'. This would mark 'yet another step in international society's journey towards ensuring that state sovereignty does not act as a veil behind which the grossest of mass human rights violations can be committed with impunity'. For Hehir and Glanville, this may remove much of what is value-added about the R2P, namely, the international remedial responsibility to react, and particularly the duty to engage in international coercive military action. Nevertheless, it does have some affinity with the 
strategy taken by the first special UN Special Adviser on the R2P, Ed Luck, who, prior to the Arab Spring, frequently downplayed - and sometimes overlooked - the potential for the R2P to involve humanitarian intervention, for fear of watering down the emerging international consensus on the R2P. This strategy, also somewhat adopted by Ban Ki-moon, has been derided by Thomas Weiss (2011) for seeking to avoid controversy, given that ' $[\mathrm{m}]$ ilitary humanitarianism is a necessary, albeit insufficient, component of the Responsibility to Protect' (p. 290). To be clear, Morris does not want to reject the case for humanitarian intervention; he thinks that the UN Security Council may still authorise military intervention, but this should be outside of the R2P framework.

In her contribution, the current UN Special Adviser on the R2P, Jennifer Welsh, also considers ways that the R2P can be taken forward in light of the Arab Spring. However, in contrast to Morris, she focuses on the issue of prevention, which is widely referred to as the most important aspect of the R2P. Drawing on a number of empirical insights on effective preventative action, she considers why prevention remains tricky and assesses efforts to implement the commitment to prevention. Welsh goes on to offer an explanation for why prevention is in fact a controversial practice - despite the universal rhetorical commitment to its prioritisation - and identifies a series of steps that might be undertaken to advance it.

As is clear from the contributions by Hehir and Glanville, some of the debate about the efficacy of the R2P depends in part on underlying debates in constructivism and Realism about the comparative import of ideational and material concerns. This debate should not simply be seen as applying the merits of Realism and constructivism, however. To a certain degree, the plausibility of either approach will be also in large part determined by the R2P. After all, the related notion of humanitarian intervention has been a central example used by constructivists in the development of their doctrine. For instance, Nicolas Wheeler's (2000) Saving Strangers and Martha Finnemore's (2004) work on humanitarian intervention are important not simply as accounts of the reasons why states engage in humanitarian intervention, but are also important contributions to constructivism per se - and in particular to the defence of the view that states may be concerned with more than simply narrow material interests. Humanitarian intervention - and potentially the $\mathrm{R} 2 \mathrm{P}$ - seems to provide a potentially clear case of where states are influenced somewhat by ideational concerns.

Notwithstanding the disagreement between them, Gifkins, Hehir, Glanville, Morris and Welsh all largely accept the normative worth of the underlying ideal of the R2P. They disagree about its practical merits and how best to realise the tackling of mass atrocities. For Hehir, and to a lesser extent Morris, the R2P lacks efficacy and so should be amended or even abandoned in favour of a less openly coercive approach (Morris) or a more legalistic and coercive one (Hehir). The underlying normative worth is, however, questioned by the last contribution.

Phillip Cunliffe claims that the Arab Spring means that we should reflect back on founding premises of the R2P, which are contained in the original ICISS report. He argues that the doctrine is normatively problematic, since it dilates the responsibilities that are owed by states to their own population. For him, the R2P is at odds with the need for representation within states. States, he claims, need to be free to decide their own destinies. There is, of course, the worry that undemocratic states will subject their 
populations to war crimes, ethnic cleansing and crimes against humanity. In addition, even democratic states may potentially subject minorities to mass atrocities or, perhaps more likely, severe repression. After all, the 'tyranny of the majority' is a commonly discussed issue in political theory and one of the central justifications for having checks on majority rule, such as in the form of human rights and, potentially, the R2P. However, this is not the only concern that Cunliffe has about the R2P. A further worry he raises is that the R2P is overly statist and imprisons populations within conflicts, being 'complicit in and productive of a highly restrictive global migration regime'. Regardless of whether one agrees with this claim, it does seem that the R2P has not been sufficiently intertwined with the R2P around refugee protection and, more broadly, international refugee law. In addition, it is clear that states have not been living up to their responsibilities in this regard. In the case of Syria, for instance, it was reported in June 2015 that the UK government had accepted only 140 refugees (Watt, 2015), which seems at odds with the underlying notion that it has a responsibility to protect citizens from beyond its borders from mass atrocities.

The articles here, therefore, do not cohere with a particular perspective on the R2P but rather constitute different elements of the debate on this most keenly contested of issues. The R2P, whatever one thinks of its merits, is likely to continue to inform debate on the international response to intra-state mass atrocities for many years and, thus, we hope these reflections on the strengths, weaknesses and efficacy to date of the concept will inform future analysis and debate.

\section{Funding}

This special issue has emerged from a three-year seminar series funded by the Economic and Social Research Council grant ES/L00075X/1, 'The Responsibility to Protect and Prosecute'. We would like to thank the funding body for its support.

\section{Note}

1. For instance, Ed Miliband (2011), the Leader of the Labour Party in the UK, invoked the R2P in the House of Commons debate on Resolution 1973, claiming that doing nothing 'would be a dereliction of our duty' (he also cites the ICISS precautionary principles). Also see the roundtable on the Libya intervention in Ethics \& International Affairs, 25(3) (2011).

\section{References}

Axworthy L and Rock A (2009) R2P: a new and unfinished agenda. Global Responsibility to Protect 1(1): 54-69.

Bellamy A (2014) From Tripoli to Damascus? Lesson learning and the implementation of the Responsibility to Protect. International Politics 51(1): 23-44.

Finnemore M (2004) The Purpose of Intervention: Changing Beliefs about the Use of Force. Ithaca, NY: Cornell University Press.

International Commission on Intervention and State Sovereignty (2001) The Responsibility to Protect. Ottawa, ON, Canada: International Development Research Centre.

Jones S and Shaheen K (2015) Syrian refugees: four million people forced to flee as crisis deepens. The Guardian, 9 July. Available at: http:/www.theguardian.com/global-development/2015/ jul/09/syria-refugees-4-million-people-flee-crisis-deepens (accessed 10 July 2015). 
Ban K (2009) Implementing the Responsibility to Protect: report of the Secretary-General. A/63/677. New York: United Nations.

Kurzman C, Fahmy DF, Gengler J, et al. (2013) Arab Winter. Contexts 12(2): 12-21.

Miliband E (2011) Hansard Parliamentary Debates, 21 March 2011, Column 716.

Thakur R and Weiss TG (2009) R2P: from idea to norm - and action? Global Responsibility to Protect 1(1): 22-53.

Watt N (2015) UK Government turning its back on Syrian refugees, says Yvette Cooper. The Guardian, 7 June. Available at: http://www.theguardian.com/uk-news/2015/jun/07/yvettecooper-uk-government-syrian-refugees (accessed 10 July 2015).

Weiss T (2011) RtoP alive and well after Libya. Ethics \& International Affairs 25(3): 287-292.

Wheeler N (2000) Saving Strangers: Humanitarian Intervention in International Society. Oxford: Oxford University Press.

\section{Author biographies}

Aidan Hehir is Reader of International Relations at the University of Westminster. He has published widely on R2P and humanitarian intervention, including The Responsibility to Protect: Rhetoric, Reality and the Future of Humanitarian Intervention (Palgrave, 2012) and Humanitarian Intervention: An Introduction (Palgrave, 2013). He also edits a series for Routledge on Intervention and Statebuilding.

James Pattison is Professor of Politics at the University of Manchester. He is the author of Humanitarian Intervention and the Responsibility to Protect: Who Should Intervene? (OUP, 2010) and The Morality of Private War: The Challenge of Private Military and Security Companies (OUP, 2014). His research interests concern ethical issues raised by international politics and he is currently working a third monograph that examines the ethics of the alternatives to military force. 